\title{
OPTIMIZATION OF THE PROCESS PARAMETERS OF FRICTION-WELDED St-Al JOINTS
}

\section{OPTIMIZACIJA PROCESNIH PARAMETROV TORNO VARJENIH ZVAROV JEKLO-Al ZLITINA}

\author{
Mumin Sahin", Cenk Misirli, Selcuk Selvi \\ Department of Mechanical Engineering, Trakya University, 22030 Edirne, Turkey \\ Prejem rokopisa - received: 2018-04-22; sprejem za objavo - accepted for publication: 2018-11-06
}

doi:10.17222/mit.2018.080

\begin{abstract}
Friction welding is a solid-state welding process, applicable to similar and dissimilar ferrous and non-ferrous metals Combining aluminium and steel parts is one of the most suitable methods for obtaining cheaper and lightweight products. Due to their different properties, compositions of these materials provide multiple advantages. In the present study, stainless-steel and aluminium (St-Al) parts were friction welded with an aim to optimize the process parameters. The joints obtained with various process-parameter combinations were subjected to tensile tests. Empirical relationships were developed to predict the strength of the joints using the RSM (the response surface methodology) and the coherency of the model was tested. The tensile properties, microhardness variations, scanning-electron-microscopy (SEM) examinations, energy-dispersive-spectroscopy (EDS) and X-ray diffraction (XRD) analyses of the welded specimens were evaluated. Additionally, the tensile-strength test results were analyzed using analysis of variance (ANOVA) with a confidence level of $95 \%$ to find a statistically significant difference. The ANOVA analysis revealed that the friction pressure/friction time ratio had a greater influence on the tensile strength of the joints than the upset pressure/upset time ratio. However, it was found that some of the stainless-steel/aluminium welds had a poor strength due to the accumulation of the alloying elements at the joint interface.

Keywords: St-Al joints, friction welding, tensile strength, response surface methodology
\end{abstract}

Torno varjenje je postopek varjenja v trdnem stanju, ki se uporablja za medsebojno spajanje podobnih ali različnih železnih in neželeznih kovin oz. zlitin. Spajanje sestavnih delov iz jekla in Al zlitin je eden od najboljših postopkov za izdelavo cenovno ugodnejših in lahkih izdelkov. Zaradi različnih lastnosti Al zlitin in jekla imajo kompoziti iz teh dveh materialov številne prednosti. V pričujoči študiji avtorji predstavljajo torno varjenje delov iz izbranega nerjavnega jekla in Al zlitine z namenom optimizacije procesnih parametrov. Trdnost spojev, izdelanih pri različnih procesnih parametrih, so preverjali z nateznim preizkusom. Razvili so empirično zvezo za napoved trdnosti spojev z uporabo metodologije odziva površine (RSM, angl.: Response Surface Methodology) in ugotavljali njeno koherenco (ustreznost). Ovrednotili so rezultate nateznih preizkusov, variiranje mikrotrdote, preiskave pod vrstičnim elektronskim mikroskopom (SEM), mikrokemijske analize (EDS) in rentgenske difrakcije (XRD) varjenih vzorcev. Dodatno so rezultate natezne trdnosti analizirali z uporabo analize variance (ANOVA) na nivoju $95 \%$ zaupanja, da bi našli statistično pomembne razlike. Analiza ANOVA je pokazala, da ima torni tlak v odvisnosti od časa trenja največji vpliv na natezno trdnost zvarnih spojev, kateremu sledi začetni tlak v odvisnosti od začetnega časa. Vendar so ugotovili, da imajo nekateri zvarni spoji nerjavnega jekla in Al zlitine slabo natezno trdnost zaradi nabiranja (akumulacije) legirnih elementov na mejni površini zvarnega spoja.

Ključne besede: zvari jeklo-Al zlitina, torno varjenje, natezna trdnost, metodologija odziva površine

\section{INTRODUCTION}

Friction welding, classified as a solid-state welding process, is one of the modern manufacturing processes with a high share in the joining of components made from dissimilar metals and alloys. Various ferrous and non-ferrous alloys with different thermal and mechanical properties can easily be joined with the friction-welding method.

The most important parameters in friction welding are friction time, friction pressure, upset time, upset pressure, rotational speed and component geometry. The establishment of a proper configuration of the process parameters has a great importance in obtaining successful joints. ${ }^{1-3}$ The effects of the three main parameters (speed of rotation, friction load and duration of welding)

*Corresponding author e-mail mumins@trakya.edu.tr on the metallurgical and mechanical properties of friction welds were studied experimentally and statistically. ${ }^{4-6}$ In the case of the fusion welding of a Fe-Al system, an excess formation of brittle intermetallic compounds degrades the joint. Since friction welding is one of the solid-state bonding procedures, few intermetallic compounds are formed at the weld interface. In the case of friction-welded pure aluminium/austenitic stainless steel joints, intermetallic compounds such as $\mathrm{Fe}_{2} \mathrm{Al}_{5}$ and $\mathrm{FeAl}_{3}$ are formed during the friction at the weld interface..$^{7-8}$ Friction-welded joint tensile properties are greatly affected by the welding parameters, and are slightly enhanced with an increased loading rate. ${ }^{9}$ However, the strength of the joint settles at a lower value, compared with that of the base metal, in the case of an increasing friction time, caused by the formation of an intermediate phase (intermetallic compound, oxides). ${ }^{10}$ The thickness of the intermetallic interlayer depends 
linearly on the square root of the friction time, indicating that the growth is caused by diffusion. ${ }^{11}$ Austenitic stainless steel is preferred over the other stainless-steel types due to its ease of use in the welding process. ${ }^{12-15}$

However, the forge-welding temperature is one of the most significant process parameters and it can greatly influence the tensile strength of a joint. ${ }^{16}$ Therefore, the mechanical and thermo-physical properties of dissimilar substrates may have a major effect on the properties of dissimilar joints because the temperature attained by each substrate depends highly on the thermo-physical properties of the two substrates and on the joining parameters selected. ${ }^{17-19}$ The joining via the welding methods of the pairs of materials, such as aluminium alloys/steel, still brings many problems..$^{20-23}$

The response surface methodology (RSM) is a collection of mathematical and statistical techniques that are useful for designing a set of experiments, developing a mathematical model, analyzing the optimum combination of the input parameters and expressing the values graphically. ${ }^{24-27}$ To obtain the maximum strength, it is essential to have a complete control over the relevant process parameters as demonstrated in the literature.

However, in this study, an attempt was made to optimize the continuous-drive friction welding of process parameters to achieve the maximum tensile strength of stainless steel/aluminium (St-Al or SS-Al) welds using the response surface methodology. Tensile tests were performed on welded test parts. Metallurgical examinations of microhardness variations were also carried out on the test parts.

\section{EXPERIMENTAL PART}

In the experiments, AISI 304 austenitic stainless steel and aluminium parts with a $10-\mathrm{mm}$ diameter were joined, using continuous-drive friction-welding process parameters. The chemical composition and mechanical properties of the stainless steel and aluminium parts are presented in Tables $\mathbf{1}$ and $\mathbf{2}$, respectively. ${ }^{28}$

Table 1: Chemical composition of the austenitic stainless steel used in the experiment ${ }^{28}$

\begin{tabular}{|c|c|}
\hline \multicolumn{2}{|c|}{ Material AISI 304 (X5CrNi1810) } \\
\hline$\% \mathrm{C}$ & $<0.07$ \\
\hline$\% \mathrm{P}$ & $<0.045$ \\
\hline$\% \mathrm{~S}$ & $<0.030$ \\
\hline$\% \mathrm{Mn}$ & $<2.0$ \\
\hline$\% \mathrm{Si}$ & $<1.0$ \\
\hline$\% \mathrm{Cr}$ & $17-19$ \\
\hline$\% \mathrm{Ni}$ & $8.5-10.5$ \\
\hline Tensile strength $(\mathrm{MPa})$ & 825 \\
\hline
\end{tabular}

Different combinations of process parameters were used for the trial runs. The process-parameter combinations were obtained by varying one of the factors while keeping the rest of them at constant values. The working range of each process parameter was determined for a smooth appearance without any observable defects. The selected levels of the process parameters and design matrix with their units and notations are presented in Tables 3 and 4.

Table 2: Chemical composition obtained with a chemical analysis of the aluminium used in the experiment

\begin{tabular}{|c|c|}
\hline \multicolumn{2}{|c|}{ Material: Aluminium } \\
\hline$\% \mathrm{Sn}$ & 0.00500 \\
\hline$\% \mathrm{~Pb}$ & 0.03360 \\
\hline$\% \mathrm{Zn}$ & 1.14000 \\
\hline$\% \mathrm{Mn}$ & 0.11800 \\
\hline$\% \mathrm{Fe}$ & 0.57400 \\
\hline$\% \mathrm{Ni}$ & 0.01220 \\
\hline$\% \mathrm{Si}$ & 0.55400 \\
\hline$\% \mathrm{Mg}$ & 0.17100 \\
\hline$\% \mathrm{Sb}$ & 0.00300 \\
\hline$\% \mathrm{Cr}$ & 0.02420 \\
\hline$\% \mathrm{Ti}$ & 0.01340 \\
\hline$\% \mathrm{Cu}$ & 0.59300 \\
\hline$\% \mathrm{Al}$ & 96.76000 \\
\hline Tensile strength $(\mathrm{MPa})$ & 200 \\
\hline
\end{tabular}

Table 3: Feasible working limits of friction-welding parameters

\begin{tabular}{|l|c|c|c|c|c|c|c|}
\hline \multicolumn{1}{|c|}{ Parameter } & \multirow{2}{*}{$\begin{array}{c}\text { Nota- } \\
\text { tion }\end{array}$} & Unit & \multicolumn{5}{c|}{ Level } \\
\cline { 4 - 8 } & & -1.68 & -1 & 0 & +1 & +1.68 \\
\hline $\begin{array}{l}\text { Friction } \\
\text { pressure/friction } \\
\text { time ratio }\end{array}$ & $\mathrm{F}$ & $\mathrm{MPa} / \mathrm{s}$ & 4.14 & 5.5 & 7.5 & 9.5 & 10.86 \\
\hline $\begin{array}{l}\text { Upset } \\
\text { pressure/upset } \\
\text { time ratio }\end{array}$ & $\mathrm{D}$ & $\mathrm{MPa} / \mathrm{s}$ & 1.64 & 3 & 5 & 7 & 8.36 \\
\hline $\begin{array}{l}\text { Rotational } \\
\text { speed/sec }\end{array}$ & $\mathrm{N}$ & $\mathrm{rps}$ & 20.14 & 21.5 & 23.5 & 25.5 & 26.86 \\
\hline
\end{tabular}

Table 4: Design matrix and the corresponding output response

\begin{tabular}{|c|c|c|c|c|c|}
\hline \multirow{2}{*}{$\begin{array}{c}\text { Standard } \\
\text { order }\end{array}$} & \multirow{2}{*}{$\begin{array}{c}\text { Run } \\
\text { order }\end{array}$} & \multicolumn{3}{|c|}{ Original value } & \multirow{2}{*}{$\begin{array}{c}\text { Tensile } \\
\text { strength }-\end{array}$} \\
\cline { 3 - 5 } & & $\mathrm{F}$ & $\mathrm{D}$ & $\mathrm{N}$ & TSP) \\
\hline 14 & 1 & 7.5 & 5 & 26.86 & 187 \\
\hline 17 & 2 & 7.5 & 5 & 23.5 & 190 \\
\hline 13 & 3 & 7.5 & 5 & 20.14 & 180 \\
\hline 15 & 4 & 7.5 & 5 & 23.5 & 189 \\
\hline 19 & 5 & 7.5 & 5 & 23.5 & 190 \\
\hline 4 & 6 & 9.5 & 7 & 21.5 & 175 \\
\hline 1 & 7 & 5.5 & 3 & 21.5 & 95 \\
\hline 8 & 8 & 9.5 & 7 & 25.5 & 178 \\
\hline 3 & 9 & 5.5 & 7 & 21.5 & 135 \\
\hline 9 & 10 & 4.14 & 5 & 23.5 & 120 \\
\hline 12 & 11 & 7.5 & 8.36 & 23.5 & 182 \\
\hline 10 & 12 & 10.86 & 5 & 23.5 & 184 \\
\hline 11 & 13 & 7.5 & 1.64 & 23.5 & 123 \\
\hline 18 & 14 & 7.5 & 5 & 23.5 & 191 \\
\hline 20 & 15 & 7.5 & 5 & 23.5 & 188 \\
\hline 5 & 16 & 5.5 & 3 & 25.5 & 145 \\
\hline 6 & 17 & 9.5 & 3 & 25.5 & 156 \\
\hline 2 & 18 & 9.5 & 3 & 21.5 & 150 \\
\hline 7 & 19 & 5.5 & 7 & 25.5 & 153 \\
\hline 16 & 20 & 7.5 & 5 & 23.5 & 191 \\
\hline
\end{tabular}


However, in order to examine the intermetallic phases formed at the interface of the joints, SEM (scanning electron microscopy) and EDS (energy dispersive X-ray spectroscopy) analyses were applied. Examinations were carried out with a JEOL JSM 5410 LV microscope and in a field of $200 \mathrm{kV}$. In addition, the weld zone of the joint was analyzed in this work since an XRD analysis of the phase constituents in the weld zone is of a great importance.

The strength of the joints is related to the hardness variation within the heat-affected zone (HAZ). The hardness variation across the welding regions of the joints was measured using $0.5 \mathrm{~kg}$ load Vickers microhardness testing.

\section{RESULTS AND DISCUSSION}

\subsection{Empirical relationships and optimization}

The response, the tensile strength $(T S)$ of frictionwelded joints, is the function of the friction-welding parameters such as the friction pressure per second $(F)$, forging pressure per second $(D)$ and rotational speed per second $(N)$. They can be expressed as:

$$
T S=f\{F, D, N\}
$$

The second-order polynomial (regression) equation used to represent the response surface $\mathrm{Y}(T S)$ is given by:

$$
Y=b_{0}+\sum b_{i} x_{i}+\sum b_{i i} x_{i}^{2}+\sum b_{i i} x_{i} x_{i}
$$

and for the three factors, the selected polynomial can be expressed as

$$
\begin{aligned}
& T S=b_{0}+b_{1}(F)+b_{2}(D)+b_{3}(N)+b_{12}(F D)+b_{13}(D N)+ \\
& +b_{11}\left(F^{2}\right)+b_{22}\left(D^{2}\right)+b_{33}\left(N^{2}\right)+
\end{aligned}
$$

\begin{tabular}{|c|c|c|c|c|c|}
\hline Source & $\begin{array}{l}\text { Sum of } \\
\text { squares }\end{array}$ & df & $\begin{array}{l}\text { Mean } \\
\text { square }\end{array}$ & F-value & \begin{tabular}{|l|} 
p-value \\
Prob. $>$ F \\
\end{tabular} \\
\hline Model & 14833.01 & 9 & 1648.11 & 17.52 & $\begin{array}{c}<0.0001 \\
\text { significant }\end{array}$ \\
\hline A-F & 4169.81 & 1 & 4169.81 & 44.32 & $<0.0001$ \\
\hline B-D & 2762.25 & 1 & 2762.25 & 29.36 & 0.0003 \\
\hline $\mathrm{C}-\mathrm{N}$ & 577.04 & 1 & 577.04 & 6.13 & 0.0327 \\
\hline $\mathrm{AB}$ & 0.12 & 1 & 0.12 & $1.329 \mathrm{E}-003$ & 0.9716 \\
\hline $\mathrm{AC}$ & 435.12 & 1 & 435.12 & 4.63 & 0.0570 \\
\hline $\mathrm{BC}$ & 153.12 & 1 & 153.12 & 1.63 & 0.2309 \\
\hline $\mathrm{A}^{\wedge} 2$ & 3709.72 & 1 & 3709.72 & 39.43 & $<0.0001$ \\
\hline $\mathrm{B}^{\wedge} 2$ & 3628.42 & 1 & 3628.42 & 38.57 & 0.0001 \\
\hline $\mathrm{C}^{\wedge} 2$ & 347.05 & 1 & 347.05 & 3.69 & 0.0837 \\
\hline Residual & 940.79 & 10 & 94.08 & & \\
\hline Lack of fit & 933.96 & 5 & 186.79 & 136.68 & $\begin{array}{c}<0.0001 \\
\text { significant }\end{array}$ \\
\hline Pure error & 6.83 & 5 & 1.37 & & \\
\hline Cor. total & 15773.80 & 19 & & & \\
\hline \multicolumn{4}{|c|}{ Std. dev. 9.70} & \multicolumn{2}{|c|}{$\begin{array}{c}0.9404 \\
\text { Adj. R-squared } 0.8867\end{array}$} \\
\hline
\end{tabular}

Table 5: ANOVA test results for the tensile-strength response
Regression coefficients are $b 1, b 2, b 3, \ldots b 44$ where $b 0$ is the average of the responses and they depend on the respective linear, interaction and squared terms of the factors as shown in the literature. ${ }^{26,27}$ The significance of each coefficient was determined with a t-test and p-values, which are listed in Table $\mathbf{5}$.

The values of the coefficients were calculated using the Design Expert Software. The values of the probability $>\mathrm{F}$ that are lower than 0.05 indicate that the model terms are significant. In this case, $F, D, N, F D, F N, D N$, $F^{2}, D^{2}$ and $N^{2}$ are significant model terms. The values greater than 0.1 point out that the model terms are not significant. The results for the multiple linear regression coefficients for the second-order response surface model are given in Table 6.

Table 6: Estimated regression coefficients

\begin{tabular}{|l|c|}
\hline \multirow{2}{*}{ Factor } & $\begin{array}{c}\text { Estimated regression } \\
\text { coefficients }\end{array}$ \\
\cline { 2 - 2 } & Tensile strength $(\mathrm{MPa})$ \\
\hline Intercept & 190.24 \\
\hline$F-$ Friction force/Friction time & 17.47 \\
\hline$D-$ Upset force/Upset time & 14.22 \\
\hline$N-$ Rotational speed & 6.50 \\
\hline$F D$ & -0.12 \\
\hline$F N$ & -7.37 \\
\hline$D N$ & -4.37 \\
\hline$F^{2}$ & -16.04 \\
\hline$D^{2}$ & -15.87 \\
\hline$N^{2}$ & -4.91 \\
\hline
\end{tabular}

The final empirical relationship was obtained using only these coefficients, and the developing final empirical relationship for the tensile strength is given below: $T S=190.24+17.47 \cdot F+14.22 \cdot D+6.50 \cdot N-0.12 \cdot F D-$ $7.37 \cdot F N-4.37 \cdot D N-16.04 c d o r F^{2}-15.87 \cdot D^{2}-4.91 \cdot N^{2}$

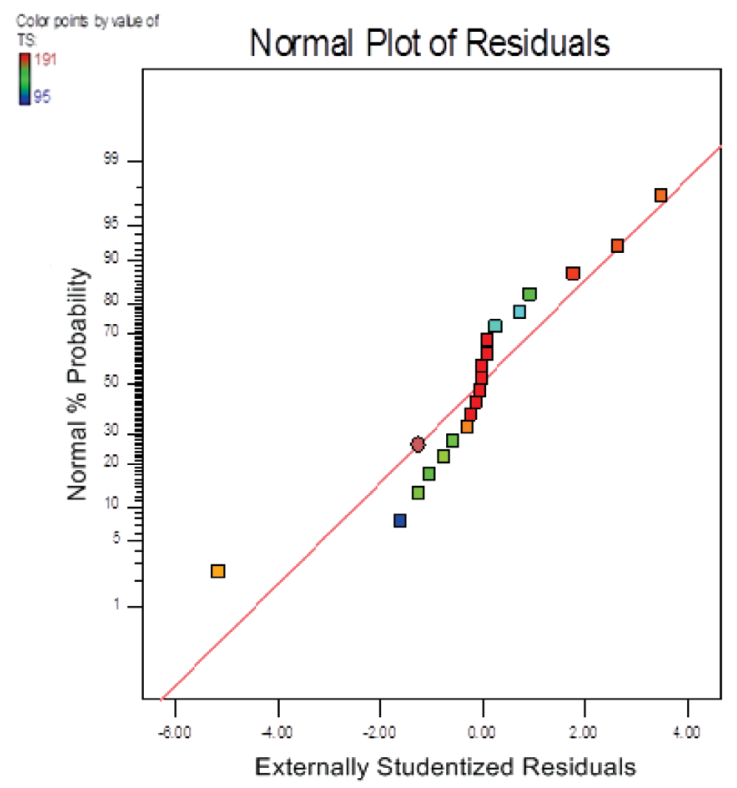

Figure 1: Normal probability plot of the residuals 


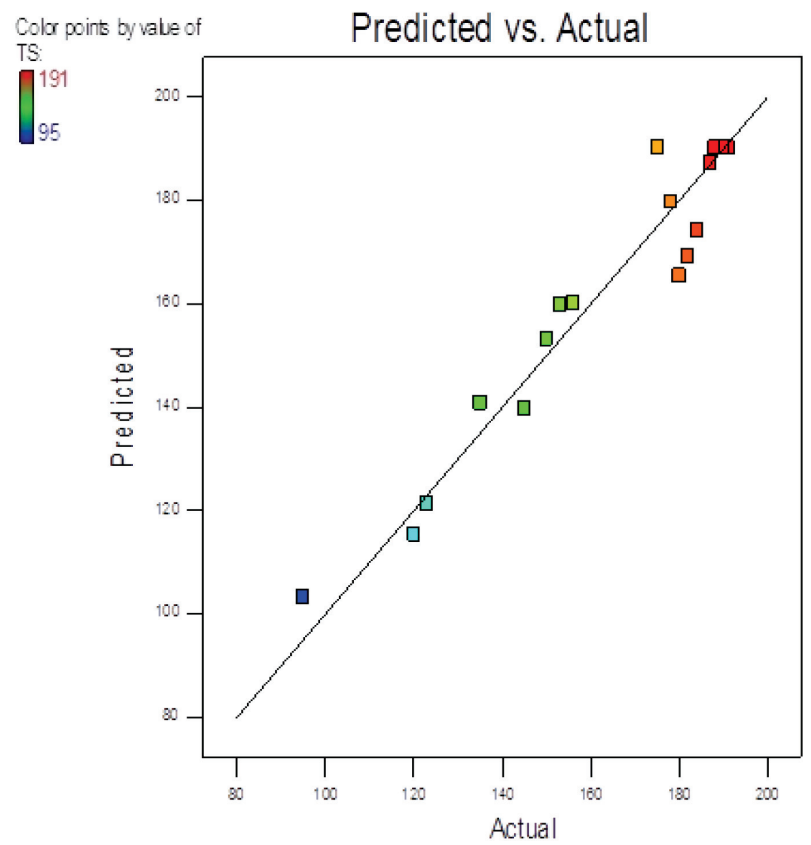

Figure 2: Correlation graph of the response

The ANOVA technique was used to check the adequacy of the developing empirical relationship. In this investigation, the desired level of confidence was $95 \%$. The relationship is considered to be adequate if the calculated F-value of the model developed does not go over the standard tabulated F-value and the calculated $R$-value of the developed relationship does exceed the standard tabulated R-value for the desired level of confidence. It is found that the above model is adequate. In the same way, interaction effects FD, FN, DN have a significant influence. A lack of fit is not significant, as it is desired. The normal probability plot of the residuals for the tensile strength is shown in Figure 1.

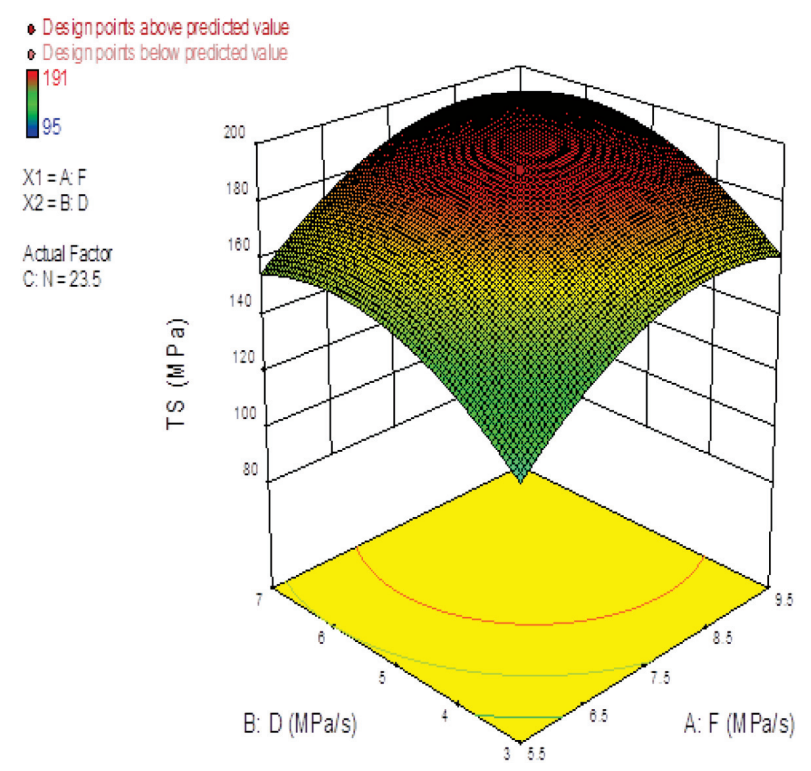

Figure 3: Response plots of the process parameters for the tensile strength

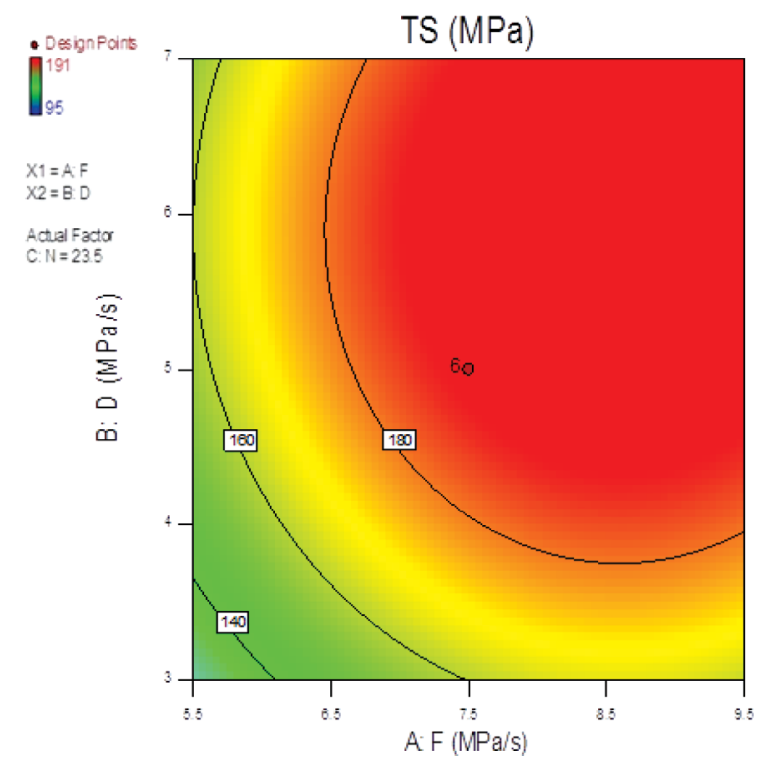

Figure 4: Contour plots of the process parameters for the tensile strength

This figure reveals that the residuals are gathered on a straight line, which means that the errors are distributed normally. Each predicted value matches well its experimental value, as shown in Figure 2.

The response surface methodology (RSM) was used to optimize the friction welding parameters in this study. The response contours can contribute to the prediction of responses in the experimental field as observed in the literature..$^{22,24-27}$ The end of the response plot illustrates the maximum achievable tensile strength. Figures $\mathbf{3}$ and 4 show that the tensile strength increases with the increasing friction pressure/time ratio and rotational speed.

The maximum tensile strength was attained under the conditions of the friction pressure/time ratio, which was 7.5 MPa/s (a friction pressure of $30 \mathrm{MPa}$ and a friction time of $4 \mathrm{~s}$ ). The upset pressure/time ratio was $5 \mathrm{MPa} / \mathrm{s}$ (an upset pressure of $60 \mathrm{MPa}$ and an upset time of $12 \mathrm{~s}$ ) and the rotational speed was $23.5 \mathrm{~s}^{-1}$, indicating the accuracy of the model.

During the welding processes, the strength of the welds obtained with dissimilar materials strongly depends on the temperature attained by each substrate.

\subsection{Metallurgical analysis}

A macrophotograph of a joint is given in Figure 5. There was no evidence of cracking or other defects in any of the joints. Due to the variations in the strength of the materials, an appreciable variation in the width of the HAZ (Heat Affected Zone) region is evident from the joints.

Furthermore, the joints exhibited more deformation on the Al side compared to the steel side (Figure 6). The microstructure of stainless steel is characterized by equiaxed grains within an austenitic grain structure, which is its natural structure at room temperature. 


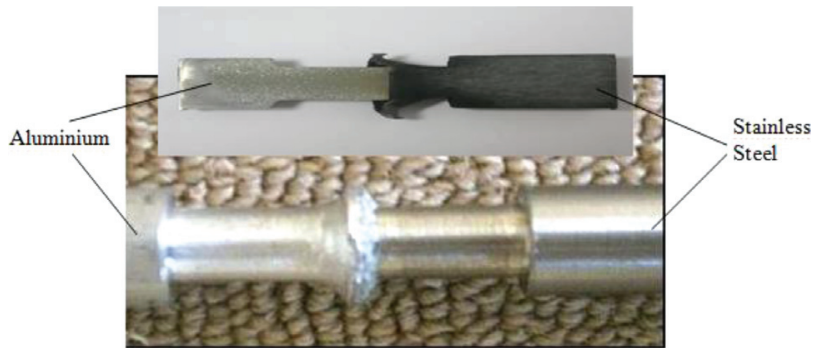

Figure 5: Macrophotograph of a joint

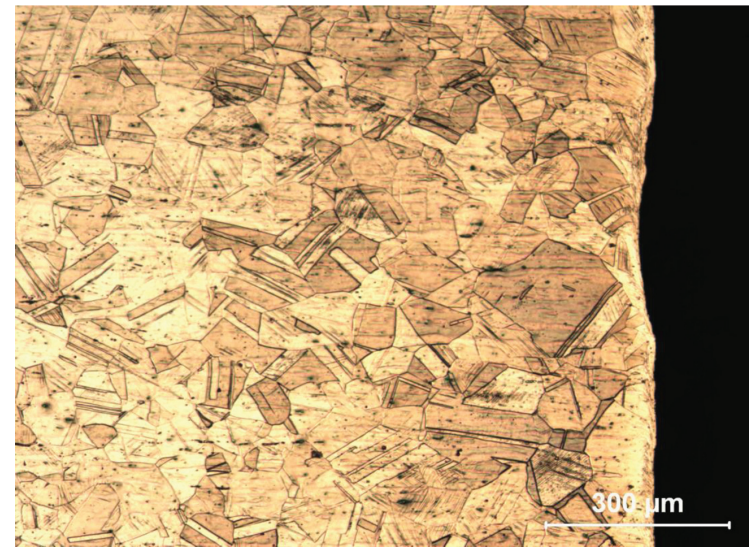

Figure 6: Microstructure of stainless steel

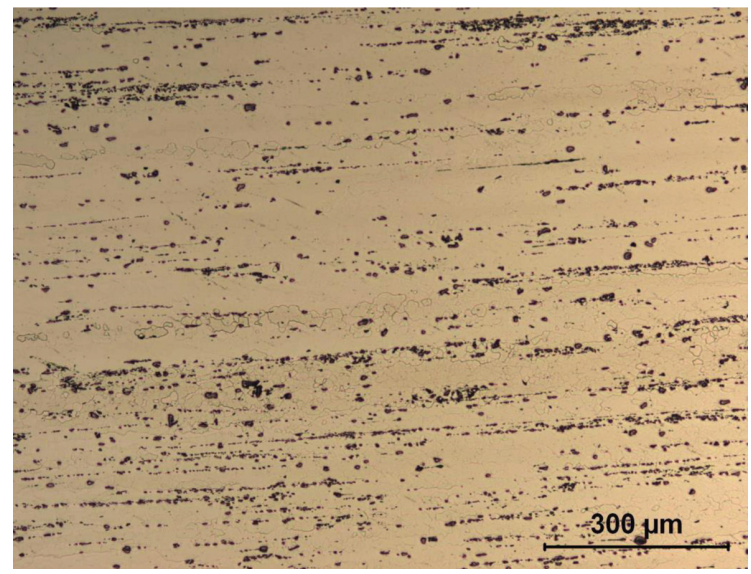

Figure 7: Microstructure of aluminium

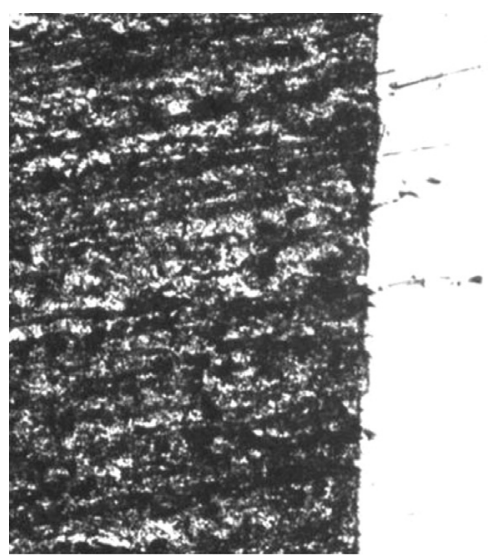

Figure 8: Microphotograph of the interface region of a joint
The following microphotographs (Figures 6 to 8 ) show that aluminium was greatly deformed, having had the grains near the weld interface elongated and refined. At the faying surface, stainless steel was slightly deformed and partly transformed from austenite to martensite due to hard friction.

Scanning-electron-microscopy (SEM) and energydispersive X-ray (EDX) analyses were performed in order to investigate the phases that occur during welding at the welding interface. An EDS point analysis was used in the examinations. The software allowed piloting the beam, scanning along a surface or a line to obtain X-ray cartography or concentration profiles by elements, respectively. The SEM microstructure of the interface region of a friction-welded steel/aluminium joint and EDX analysis results are given in Figure 9, while the distribution of the elements within a determined location is shown in Table 7.

Table 7: EDS-point-analysis results according to the SEM microstructure $(w / \%)$

\begin{tabular}{|c|c|c|c|c|}
\hline Points & Elements & Line & $\begin{array}{c}\text { Intensity } \\
(\mathrm{c} / \mathrm{s})\end{array}$ & Conclusion \\
\hline 1 & $\mathrm{Al}$ & $\mathrm{Ka}$ & 1928.84 & $\begin{array}{c}100.000 \% \\
100.000 \% \text { Total }\end{array}$ \\
\hline 2 & $\mathrm{Al}$ & $\mathrm{Ka}$ & 1201.79 & $97.792 \%$ \\
& $\mathrm{Fe}$ & $\mathrm{Ka}$ & 10.30 & $2.208 \%$ \\
& & & & $100.000 \%$ Total \\
\hline 3 & $\mathrm{Al}$ & $\mathrm{Ka}$ & 57.68 & $36.742 \%$ \\
& $\mathrm{Cr}$ & $\mathrm{Ka}$ & 34.29 & $17.651 \%$ \\
& $\mathrm{Fe}$ & $\mathrm{Ka}$ & 60.68 & $45.607 \%$ \\
& & & & $100.000 \%$ Total \\
\hline 4 & $\mathrm{Al}$ & $\mathrm{Ka}$ & 97.01 & $21.117 \%$ \\
& $\mathrm{Cr}$ & $\mathrm{Ka}$ & 79.18 & $11.282 \%$ \\
& $\mathrm{Mn}$ & $\mathrm{Ka}$ & 76.10 & $12.472 \%$ \\
& $\mathrm{Fe}$ & $\mathrm{Ka}$ & 255.17 & $55.128 \%$ \\
& & & & $100.000 \%$ Total \\
\hline 5 & $\mathrm{Cr}$ & $\mathrm{Ka}$ & 370.48 & $18.189 \%$ \\
& $\mathrm{Fe}$ & $\mathrm{Ka}$ & 958.19 & $75.092 \%$ \\
& $\mathrm{Ni}$ & $\mathrm{Ka}$ & 58.40 & $6.719 \%$ \\
& & & & $100.000 \%$ Total \\
\hline
\end{tabular}

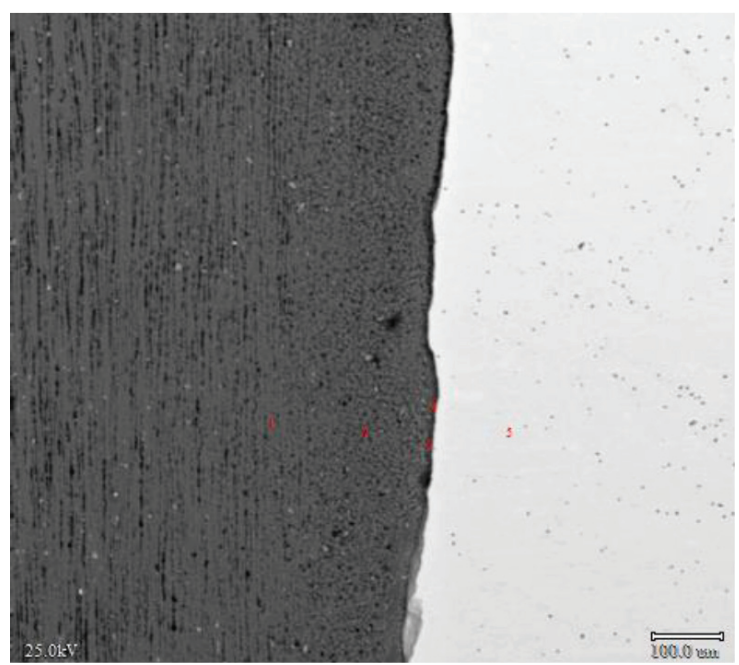

Figure 9: SEM microstructure of a joint interface with analysis points 


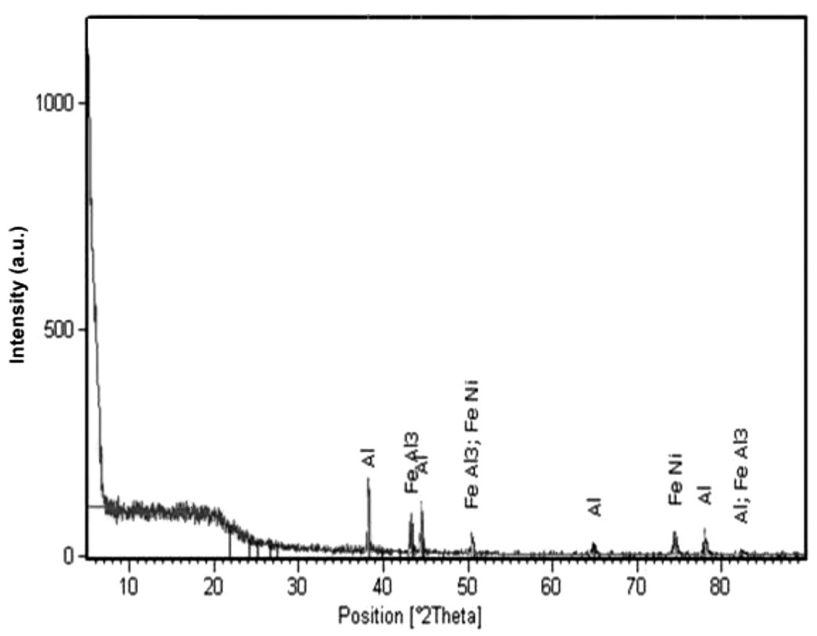

Figure 10: XRD results for the weld zone of the joints

The EDS analysis was carried out for various points of the SEM image.

Figure 9a shows the EDX analysis points defined in the SEM microstructure of the interface region of a friction-welded St-Al joint.

Table 7 shows the EDS-point-analysis results represented by SEM. The EDS results confirmed that St-Al joints contain certain intermetallic compounds. Therefore, the formation of brittle intermetallic compounds reduces the strength of the joints.

An XRD analysis of the phase constituents in the weld zone is quite important. In this experiment, the weld zone of a joint was analyzed. The XRD results for the weld zone of the joints are given in Figure 10.

The constituent elements of both materials interdiffused through the weld interface and intermetallic compounds such as $\mathrm{FeAl}, \mathrm{Fe}_{3} \mathrm{Al}, \mathrm{AlFe}, \mathrm{AlFe}_{3}$ and $\mathrm{FeNi}$ were formed at the weld interface.

\subsection{Microhardness measurement}

Microhardness was measured for the joints across the weld region and the values were plotted as shown in Figure 11.

The maximum microhardness was reached at the interface and this may be due to the formation of brittle intermetallic compounds. This is one of the reasons for a lower tensile strength of dissimilar joints.

\section{CONCLUSIONS}

Friction-welded stainless-steel and aluminium parts were successfully joined in this study. The following important conclusions were obtained from this investigation:

- A proper selection of the optimum welding parameters is crucial for friction-welded joints.

- Empirical relationships were developed to predict the tensile strength of the friction-welded stainless-steel

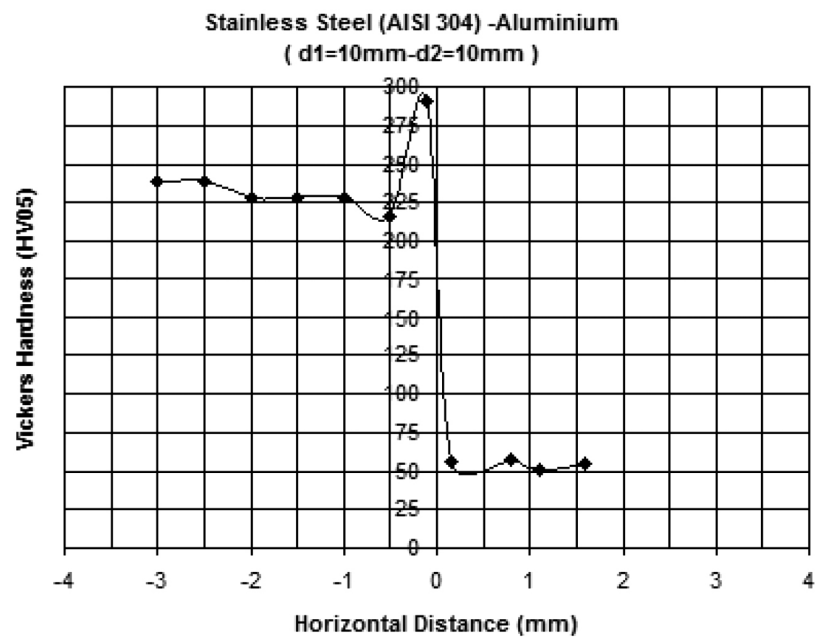

Figure 11: Microhardness variation across a joint

and aluminium parts, incorporating process parameters at a $95-\%$ confidence level.

- Friction-welding parameters were optimized with the response surface methodology to obtain the maximum tensile strength. The maximum tensile strength of $191 \mathrm{MPa}$ was attained for the friction-welded joints under the welding conditions including a friction pressure/time ratio of $7.5 \mathrm{MPa} / \mathrm{s}$, an upset pressure/time ratio of $5 \mathrm{MPa} / \mathrm{s}$ and a rotational speed of $23.5 \mathrm{~min}^{-1}$.

- The friction pressure/friction time ratio was found to have a greater influence on the tensile strength of the joints than the upset pressure/upset time ratio.

- Various intermetallic phases such as FeAl, $\mathrm{Fe}_{3} \mathrm{Al}$, $\mathrm{AlFe}, \mathrm{AlFe}_{3}$ and FeNi occurred at the interface. The formation of intermetallics at the interface is responsible for a higher hardness and lower tensile strength of the friction-welded stainless steel/aluminium joints. The intermetallic phases at the interface may also play a significant role in hardness variations.

\section{Acknowledgment}

The author would like to thank Trakya University/ Edirne - Turkey, Hema Industry/Cerkezkoy - Turkey and TUBITAK MRC/Gebze - Turkey for the help in the experimental part of the study.

\section{REFERENCES}

${ }^{1}$ V. I. Vill, Friction Welding of Metals, AWS, Newyork, 1962

${ }^{2}$ W. Kinley, Welding and Metal Fabrication, 1979, 585-589

${ }^{3}$ N. I. Fomichev, Welding Production, 1980, 35-38

${ }^{4}$ B. S. Yilbas, A. Z. Sahin, N. Kahraman, A. Z. Al-Garni, Friction welding of St-Al and Al-Cu materials, Journal of Materials Processing Technology, 49 (1995) 3-4, 431-443, doi:10.1016/09240136(94)01349-6

${ }^{5}$ B. S. Yilbas, A. Z. Sahin, A. Coban, B. J. Abdul Aleem, Investigation into the properties of friction-welded aluminium bars, Journal of Materials Processing Technology, 54 (1995), 76-81, doi:10.1016/ 0924-0136(95)01923-5 
${ }^{6}$ C. G. Rhodes, M. W. Mahoney, W. H. Bingel, R. A. Spurling, C. C. Bampton, Effects of friction stir welding on microstructure of 7075 aluminium, Scripta Materialia, 36 (1997) 1, 69-75, doi:10.1016/ S1359-6462(96)00344-2

${ }^{7}$ S. Fukumoto, H. Tsubakino, K. Okita, M. Aritoshi, T. Tomita Friction welding process of 5052 aluminium alloy to 304 stainless steel, Materials Science and Technology, 15 (1999), 1080-1086, doi:10.1179/026708399101506805

${ }^{8}$ S. Fukumoto, H. Tsubakino, K. Okita, M. Aritoshi, T. Tomita Amorphization by friction welding between 5052 aluminum alloy and 304 stainless steel, Scripta Materialia, 42 (2000), 807-812, doi:10.1016/S1359-6462(00)00299-2

${ }^{9} \mathrm{~T}$. Yokoyama, Impact performance of friction welded butt joints between 6061-T6 aluminium alloy and type 304 stainless steel, Materials Science and Technology, 19 (2003), 1418-1426, doi:10.1179/026708303225007960

${ }^{10}$ W. B. Lee, M. Yeon, D. U. Kim, S. B. Jung, Effect of friction welding parameters on mechanical and metallurgical properties of aluminium alloy 5052-A36 steel joint, Materials Science and Technology, 19 (2003), 773-778, doi:10.1179/026708303225001876

${ }^{11}$ M. Yilmaz, M. Col, M. Acet, Interface properties of aluminum/steel friction-welded components, Materials Characterization, 49 (2003), 421-429, doi: 10.1016/S1044-5803(03)00051-2

${ }^{12}$ M. Sahin, An investigation into joining of austenitic-stainless steels (AISI 304) with friction welding, Assembly Automation, 25 (2005) 2, 140-145, doi:10.1108/01445150510590505

${ }^{13}$ M. Sahin, Evaluation of the joint-interface properties of austenitic-stainless steels (AISI 304) joined by friction welding, Materials and Design, 28 (2007) 7, 2244-2250, doi:10.1016/j.matdes.2006. 05.031

${ }^{14}$ M. Sahin, Characterization of properties in plastically deformed austenitic-stainless steels joined by friction welding, Materials and Design, 30 (2009) 1, 135-144, doi:10.1016/j.matdes.2008.04.033

${ }^{15}$ M. Sahin, Joining of stainless-steel and aluminium materials by friction welding, International Journal of Advanced Manufacturing Technology, 41 (2009), 487-497, doi:10.1007/s00170-008-1492-7

${ }^{16}$ T. F. Kong, L. C. Chan, T. C. Lee, Experimental study of effects of process parameters in forge-welding bimetallic materials: AISI $316 \mathrm{~L}$ stainless steel and 6063 aluminium alloy, Strain, 45 (2009) 4, 373-379, doi: 10.1111/j.1475-1305.2008.00445.x

${ }^{17}$ P. Sammaiah, A. Suresh, G. R. N. Tagore, Mechanical properties of friction welded 6063 aluminium alloy and austenitic stainless steel,
Journal of Materials Science, 45 (2010), 5512-5521, doi:10.1007/ s10853-010-4609y

${ }^{18}$ M. B. Uday, M. N. A. Fauzi, H. Zuhailawati, A. B. Ismail, Advances in friction welding process: A review, Science and Technology of Welding and Joining, 15 (2010) 7, 534-558, doi:10.1179/ 136217110X12785889550064

${ }^{19}$ R. N. Shubhavardhan, S. Surendran, Friction welding to join stainless steel and aluminum materials, International Journal of Metallurgical and Materials Science and Engineering (IJMMSE), 2 (2012) 3, 53-73

${ }^{20}$ A. Ambroziak, M. Korzeniowski, P. Kustroń, M. Winnicki, P. Sokołowski, E. Harapińska, Friction welding of aluminium and aluminium alloys with steel, Advances in Materials Science and Engineering, (2014), 1-15, doi: 10.1155/2014/981653

${ }^{21}$ K. Reddi Prasad, V. G. Sridhar, Evaluating the capability, joining and characterization of similar and dissimilar pipes by friction welding process - Review, International Journal of Applied Engineering Research, 11 (2016) 5, 3681-3688

${ }^{22}$ T. P. Chen, W. B. Lin, Optimal FSW process parameters for interface and welded zone toughness of dissimilar aluminium-steel joint, Science and Technology of Welding and Joining, 15 (2010) 5, 279-285, doi: 10.1179/136217109X12518083193711

${ }^{23}$ M. Sahin, Characterization of properties in friction-welded austenitic-stainless steel and aluminium joints, Industrial Lubrication and Tribology, 66 (2014) 2, 260-271, doi: 10.1108/ILT-11-20110100

${ }^{24}$ L. K. Bhagi, S. Singh, I. Singh, Application of Taguchi method for optimization of continuous drive friction welding process parameters, Ukrainian Journal of Mechanical Engineering and Materials Science, 2 (2016) 1, 1-10

${ }^{25} \mathrm{M}$. Sahin, Optimizing the parameters for friction welding stainless steel to copper parts, Mater. Tehnol., 50 (2016) 1, 109-115, doi: 10.17222/mit.2015.023

${ }^{26}$ G. E. P. Box, W. H. Hunter, J. S. Hunter, Statistics for experiment, New York: John Wiley Publications, 1978

${ }^{27}$ A. I. Khuri, J. Cornell, Response Surfaces: Designs and Analyses, Marcel Dekker, New York, 1996

${ }^{28}$ C. W. Wegst, Stahlschlüssel, Verlag Stahlschlüssel Wegst GmbH, D-71672 Marbach, 1995 